\title{
DETERMINATION OF INDONESIAN NATIVE STINGLESS BEE PROPOLIS AS COMPLEMENTARY NUTRACEUTICAL CANDIDATE OF ANTI-TUBERCULOSIS DRUG
}

\author{
MAHANI ${ }^{1,2}$, A. SULAEMAN ${ }^{1}$, F. ANWAR ${ }^{1}$, M. R. M. DAMANIK ${ }^{1}$, HARDINSYAH ${ }^{1}$, A. PLOEGER ${ }^{3}$
}

${ }^{1}$ Department Community Nutrition, Faculty of Human Ecology, Bogor Agricultural University, Indonesia, ${ }^{2}$ Department Food Industrial Technology, Faculty of Agro-Industrial Technology, Padjadjaran University, Indonesia, ${ }^{3}$ Department Organic Food Quality and Food Culture, Faculty of Organic Agricultural Sciences at Kassel University, Germany Email: asulaema06@gmail.com

Received: 06 Feb 2017 Revised and Accepted: 24 Feb 2018

\begin{abstract}
Objective: This study aimed to determine Indonesian native stingless bee propolis from ten provinces of Indonesia as complementary nutraceutical candidate of anti-tuberculosis drug (ATD).

Methods: Propolis samples were collected from stingless bee cultivated in ten provinces of Indonesia. The antioxidant capacity test was performed using 2,2-diphenyl-1-picrylhydrazyl and toxicity test was done using Brine Shrimp Lethality Test. The inhibition test of Mycobacterium tuberculosis $(M t b)$ was performed using Lowenstein-Jensen medium and bacterial colonies were estimated using Most Probable Number.

Results: The highest antioxidant capacity was found in Geniotrigona incisa (G. incisa) propolis from South Sulawesi Province with an IC 50 of 100.05 ppm, while the lowest antioxidant capacity was found in Tetragonula minangkabau propolis from North Sumatera Province with an IC 50 of 1378.90 $\mathrm{ppm}$. The lowest propolis toxicity was found in Geniotrigona thorasica propolis from South Kalimantan Province with an $\mathrm{LC}_{50}$ of $>1000.00$, while the highest propolis toxicity was found in Tetragonula laeviceps (T. laeviceps) propolis from Banten Province with an $\mathrm{LC}_{50}$ of $<50.00$. T. laeviceps propolis from Banten Province had the lowest Mtb inhibition, with the inhibition value of $1.59 \%$. On the other hand, the highest inhibition was shown by Tetragonula biroi propolis from South Sulawesi Province and Tetragonula fuscobalteata propolis from West Nusa Tenggara Province with $100 \%$ inhibition value (equivalent to rifampicin).
\end{abstract}

Conclusion: Based on all determinant parameters, G. incisa propolis from South Sulawesi Province has the highest score, and it is defined as complementary nutraceutical candidate of ATD.

Keywords: Indonesian, Nutraceutical, Propolis, Stingless bee, Tuberculosis

(C) 2018 The Authors. Published by Innovare Academic Sciences Pvt Ltd. This is an open access article under the CC BY license (http://creativecommons.org/licenses/by/4.0/) DOI: http://dx.doi.org/10.22159/ijpps.2018v10i4.23850

\section{INTRODUCTION}

Tuberculosis (TB) is a global infectious disease problem and the second leading cause of death after HIV/AIDS infection. Indonesia ranks $2^{\text {nd }}$ out of 30 countries in the world in terms of TB epidemic, and it is categorized as a high-burden country [1]. One of the problems encountered in the use of the anti-tuberculosis drug (ATD) is the hepatotoxic effect $[2,3]$. The hepatotoxic effects of ATD may cause decreased appetite, nausea, dizziness, insomnia, fever and weight loss $[4,5]$, thereby decreasing nutritional status of the patients, whereas good nutritional status strongly supports the healing process [6].

Hepatotoxicity mechanism of rifampicin is mediated by oxidative damage. The antioxidant mechanism in reducing reactive oxygen species (ROS) is strongly suspected as a hepatoprotective mechanism of liver toxicity $[7,8]$. Therefore, the provision of antioxidants is expected to reduce the hepatotoxic effects of ATD. Numerous studies have shown that propolis is an antioxidant and able to protect the liver from toxic effects of drugs and ATD [9-13]. Propolis also provides a great protection from the hematologic toxicity of rifampicin and isoniazid [14].

Stingless bee propolis has strong antibacterial activity [15-16], and it strongly inhibits Streptococcus sanguinis [17] and Streptococcus mutans [18]. Propolis also has the ability to fight TB infection [19]. Numerous studies have revealed that propolis synergizes with ampicillin, gentamycin, and streptomycin to kill Mycobacterium tuberculosis (Mtb) [20]; synergizes with streptomycin, rifampicin, isoniazid, and ethambutol [21]; and synergizes with streptomycin and cloxacillin [22]. Therefore, propolis is an ideal material as an ATD complementary nutraceutical for pulmonary TB healing. Administration of propolis-equipped ATD is expected to reduce the hepatotoxic effects in TB patients and strengthen the ability to fight TB infection.
Indonesia has a large diversity of propolis sources, due to the diversity of bee species and vegetation of resin sources. It is therefore very interesting to examine biological activities (antioxidant activity, toxicity, and inhibition of $M t b$ ) of propolis from various provinces in order to discover the propolis that is able to resist ATD toxic effects, having low toxicity and is able to inhibit $M t b$ infection.

This study aimed to determine Indonesian native stingless bee propolis from ten provinces in Indonesia as complementary nutraceutical candidate of ATD.

\section{MATERIALS AND METHODS}

\section{Propolis samples and chemicals}

Fourteen different stingless bee propolis samples were collected from stingless bee farm in ten provinces in Indonesia, namely Tetragonula minangkabau (T. minangkabau) and Tetragonula moorei (T. moorei) from North Sumatera Province, Tetragonula laeviceps (T. laeviceps) from Banten Province, T. laeviceps from West Java Province, T. laeviceps from Central Java Province, Heterotrigona itama (H. itama) from West Kalimantan Province, H. itama from East Kalimantan Province, H. itama, Geniotrigona thorasica (G. thorasica) and T. laeviceps from South Kalimantan Province, Geniotrigona incisa (G. incisa) and Tetragonula biroi (T. biroi) from South Sulawesi Province, Tetragonula fuscobalteata (T. fuscobalteata) from West Nusa Tenggara Province, and T. fuscobalteata from North Maluku Province. The chemicals used were $70 \%$ hydroethanolic extract, 2,2 diphenyl-1-picrylhydrazyl (DPPH), methanol, dimethyl sulfoxide (DMSO), Trolox, and tween $80 \%$ that were obtained from Sigma/Aldrich Co. through distributor company in Jakarta, Indonesia. Rifampicin was obtained from a drugstore in Bogor, Indonesia. 


\section{Extraction of propolis}

All of the propolis samples were chopped into small pieces and macerated with $70 \%$ hydroethanolic extract (ratio of sample and ethanol $=1: 3$ ) by using water bath shaker at room temperature for 2 $\mathrm{d}$. The filtrate was collected and the residue was macerated two times under the same condition. After filtration, the filtrate was evaporated by a rotary evaporator $\left(3 \mathrm{rpm}\right.$ at $\left.60^{\circ} \mathrm{C}\right)$ and then the pure propolis extract was collected.

\section{Free radical scavenging activity test-2,2-diphenyl-1-picrylhydrazyl} (DPPH)

The free radical scavenging activity was measured using DPPH [23]. Briefly, various propolis extract solutions $(2 \mathrm{mg} / \mathrm{ml})$ were added to $2 \mathrm{ml}$ of DPPH, dissolved in methanolic solution $(0.1192 \mathrm{mmol} / \mathrm{l})$, and maintained in the dark for $30 \mathrm{~min}$ at room temperature. The absorbance was then measured at $517 \mathrm{~nm}$. Methanol was used instead of propolis extract solutions as a control and Trolox was used as a positive control. The results were expressed with $\mathrm{IC}_{50}$ value (50\% inhibitory concentration), which determined the extract concentration $(\mu \mathrm{g} / \mathrm{ml})$ that provided $50 \%$ inhibition. The lower of the value is the greater of the capacity of the antioxidant. The scavenging capacity of the DPPH radical was calculated with the equation below (percent inhibition of the DPPH radical).

$$
\% \text { Inhibition of DPPH }=\frac{(\text { Abs DPPH }- \text { Abs sample1) }}{\text { Abs DPPH }} \times 100
$$

The extract concentration value was plotted against the percent inhibition of DPPH. and the $\mathrm{IC}_{50}$ value was obtained by linear regression. All treatments were run in triplicate.

\section{Toxicity test-brine shrimp lethality test (BSLT)}

We used preliminary toxicity of BSLT by using Artemia salina Leach [24]. Artemia cysts were prepared by Biopharmaceutical Research Center (BRC), Bogor Agricultural University, Indonesia. The cysts were hatched in the laboratory using artificial seawater at $27-30{ }^{\circ} \mathrm{C}$ medium. Appropriate light, $\mathrm{pH}$ of 7.5-8.5, alkaline water with a salinity of $3 \%$ and temperature of $27-30{ }^{\circ} \mathrm{C}$ were regulated during the test. The larvae were collected from hatcheries with a plastic pipette for $\mathrm{LC}_{50}$ study.

$\mathrm{LC}_{50}$ was estimated in five dilutions $(250,500,750,1000$ and 1500 $\mu \mathrm{g} / \mathrm{ml}$ ) of propolis extracts for $24 \mathrm{~h}$. In each plate, $0.5 \mathrm{ml}$ of propolis extract with different concentrations was added to $4.5 \mathrm{ml}$ of the brine shrimp solution. Ten brine shrimp larvae that had been grown for $48 \mathrm{~h}$ were added to each plate. For each propolis concentration, one DMSO with $4.5 \mathrm{ml}$ of brine shrimp solution without propolis extract was used as a control. The plates were sealed with their lids in the darkness at room temperature for $24 \mathrm{~h}$. During the test, feeding and aeration were not allowed. After $24 \mathrm{~h}$, the number of dead and surviving larvae was counted on the plates, and cytotoxicity of the samples was then determined. Each experiment was performed in triplicate. During each experiment, if mortality of the control group was more than $10 \%$ of the experiment group, the procedure must be repeated. The mortality was calculated using the following formula:

$$
\text { Mortality }=\frac{\text { Accumulation of death larvae }}{\text { Accumulation of death }+ \text { surviving larvae }} \times 100 \%
$$

The graph was constructed with log concentration as the $\mathrm{x}$-axis and mortality as the y-axis. A substance was confirmed as toxic when $\mathrm{LC}_{50}$ of the extract was less than $1000 \mathrm{ppm}$ and $\mathrm{LC}_{50}$ of the pure compound was less than $30 \mathrm{ppm}$.

\section{Mycobacterium tuberculosis inhibition test-proportion method}

Mycobacterium tuberculosis inhibition test was based on $100 \%$ inhibitory concentration by ATD (i.e. rifampicin). At $0.02 \%$ rifampicin concentration, all tests consistently showed no Mtb growth (100\% inhibition). Hence, the concentration was used as the standard sample concentration. Therefore, sample concentration also used the same concentration.

\section{Suspension preparation}

Sterile screw-cap tubes were filled with 10 glass beads and 1 drop of $0.1 \%$ tween $80 \%$. The tubes were then weighed and recorded, for example, M1. Mtb H37Rv colony aged 3-6 w was taken with inoculating loop, inserted into the tube, then weighed again, for instance, M2. Weight of Mtb H37Rv = M2-M1 = M3. The tube contained Mtb H37Rv was vortexed into homogeneous solution and set aside for $10 \mathrm{~min}$ to let aerosol down. Sterile distilled water in M3 $\mathrm{mg}(1 \mathrm{ml} \sim 1 \mathrm{mg})$ was added and homogenized using vortex for 2 min. Finally, it was set aside until the precipitate of coarse particles was formed and the supernatant seemed clear.

\section{Inoculation}

A $100 \mu$ l supernatant was taken by automatic pipette and yellow tip and inserted into a threaded tube containing Lowenstein Jensen (LJ) medium. There were three kinds of LJ medium, namely a) LJ medium without rifampicin and propolis (negative control), b) LJ medium with rifampicin (positive control), and c) LJ medium with propolis sample (consisting of 14 propolis samples). Two replications of each inoculation were made. The supernatant (inoculation fluid) was flattened to cover the entire surface of the medium.

\section{Colony counting}

The colonies growing on the media surface in screw-cap tubes were counted manually with a magnifying glass. The number of colonies was recorded as the Most Probable Number (MPN).

\section{Interpretation}

The MPN on negative control was considered as $100 \%$ growth. Furthermore, inhibition of $M t b$ in propolis sample could be calculated by the following calculation:

Mtb inhibition activity of the sample $=100-\%$ growth of Mtb

\section{Determination of the best candidate}

The best candidate was determined based on the total score of each propolis sample obtained from three parameters; i.e. antioxidant capacity, toxicity, and $M t b$ inhibition activity. Antioxidant scores were obtained by sequencing $\mathrm{IC}_{50}$ values of propolis samples. The smaller the value of $\mathrm{IC}_{50}$, the more powerful the biological activity and the greater the score. The lowest score was 1 and the highest score was 14 (according to the number of propolis samples). If there were more than one sample having the same $\mathrm{IC}_{50}$ score, the same score was given so that the highest score was less than 14. Inhibition score of $M t b$ was obtained by sequencing the inhibition value (\%). The greater the inhibition percentage (\%), the greater the score. If more than one sample had the same inhibition percentage (\%), the same score was given so that the highest score was less than 14. The toxicity score was obtained from $\mathrm{LC}_{50}$ value. The smaller the $\mathrm{LC}_{50}$ value, the greater the toxicity. The desired propolis was the one with low toxicity. The greater the toxicity, the smaller the score. The method to sort the scores was similar to the determination of other parameter scores.

Referring to hepatotoxicity problem in the use of ATD in TB treatment, the desired nutraceutical propolis was the one which has a strong hepatoprotective activity to reduce the hepatotoxic effects of ATD. Rifampicin hepatotoxicity mechanism is mediated by oxidative damage [7], and antioxidant mechanism in reducing ROS is strongly suspected as a hepatoprotective mechanism of liver toxicity $[8,25]$. Therefore, the antioxidant capacity of the sample became the main parameter and had the greatest weight. Additionally, the determination of propolis as the complementary of ATD also considered patient safety (low toxicity) and Mtb inhibition ability that could strengthen ATD to fight infection. The weight distribution of determinant parameters was presented in the following table:

Table 1: Determinant parameters and their weighting

\begin{tabular}{ll}
\hline Parameter & Weighting (\%) \\
\hline Antioxidant capacity & 50 \\
Mtb inhibition activity & 25 \\
Toxicity & 25 \\
Total & 100 \\
\hline
\end{tabular}

Propolis sample that obtained the highest total score was defined as a complementary nutraceutical candidate of ATD. 


\section{RESULTS AND DISCUSSION}

\section{Antioxidant capacity}

Antioxidant capacity was indicated by $\mathrm{IC}_{50}$ value. The greater the $\mathrm{IC}_{50}$ value, the weaker the antioxidant activity. Conversely, the lower the $\mathrm{IC}_{50}$ value, the more powerful the antioxidant activity. This study showed that T. minangkabau propolis from North Sumatera Province had the weakest antioxidant capacity ( IC $_{50}$ of 1378.95 ppm), whereas G. incisa propolis from South Sulawesi Province had the strongest antioxidant capacity ( $\mathrm{IC}_{50}$ of $100.05 \mathrm{ppm}$ ).

The difference in antioxidant capacity of propolis might be due to the difference in the composition of the active compounds in it. The more the active compounds that have antioxidant properties and the stronger the activity, the stronger the antioxidant capacity of a propolis. This assumption is strengthened by the results of the previous study which has suggested that propolis with different phytochemical composition produces different antioxidant capacity [23].

The strength of propolis's antioxidant capacity is influenced by two factors. The first one is the bee species differences; i.e. different bee species have different tastes on plant resins. In this study, G. incisa propolis and $T$. biroi propolis came from the same farm with the availability of the same resin source plant. However, both propolis had different antioxidant capacities. These findings strengthen the opinion that each bee species has a unique and different behaviour from other bee species [26]. The second one is the difference in resin source plant. Each plant resin has a unique and distinctive active compound composition between plant species. The difference is very influential on the composition of the active compounds contained in the plant and on its antioxidant capacity. Silymarin is a phytochemical that has an antioxidant activity and is an excellent hepatoprotector [27, 28], propolin $G$ has a strong anticancer activity [29], glycosides have strong anti Mtb [30], and quercetin has strong antioxidant and antitumor activities [31].

The strength of the antioxidant capacity of $G$. incisa bee propolis is associated with the number of medicinal plants that become its resin sources. The plants are kaju landong (Paraserianthes falcataria), palili (Lithocarpus celebica Rehder), annaja (Saurauia costata), poringan (Baccaurea sp), uru (Arenga pinnata), and sempur (Dillenia indica). These plants are known as medicinal plants by local people. G. incisa bees also take resin from food plants, namely mango (Mangifera indica) and durian (Durio ziberthinus).

Related to antioxidant function, hepatotoxicity mechanism of rifampicin is mediated by oxidative damage $[7,32]$. Isoniazid also causes liver damage and it can be reduced by strong antioxidant compounds [25]. The silymarin (a plant phytochemical compound with strong antioxidant activity) has been proven to protect the liver from toxic effects of isoniazid, rifampicin, and pyrazinamide and has low toxicity [27].

Table 2: Antioxidant capacity of stingless bee propolis samples from different provinces

\begin{tabular}{|c|c|c|c|c|}
\hline Province origin & Bee Species & IC $_{50}$ Antioxidant capacity $(\mathrm{ppm})^{\mathrm{a}}$ & Score order & Weighting score $(50 \%)$ \\
\hline North Sumatera & T. minangkabau & $1378.95 \pm 16.67$ & 1 & 0.5 \\
\hline North Sumatera & S. moorei & $208.92 \pm 9.57$ & 12 & 6.0 \\
\hline Banten & T. laeviceps & $150.83 \pm 0.21$ & 13 & 6.5 \\
\hline West Java & T. laeviceps & $574.85 \pm 4.49$ & 6 & 3.0 \\
\hline Central Java & T. laeviceps & $283.05 \pm 20.44$ & 9 & 4.5 \\
\hline West Kalimantan & H. itama & $227.54 \pm 9.32$ & 10 & 5.0 \\
\hline East Kalimantan & H. itama & $939.98 \pm 6.51$ & 2 & 1.0 \\
\hline South Kalimantan & H. itama & $636.61 \pm 11.28$ & 4 & 2.0 \\
\hline South Kalimantan & T. laeviceps & $580.40 \pm 8.61$ & 5 & 2.5 \\
\hline South Kalimantan & G. thorasica & $905.06 \pm 7.96$ & 3 & 1.5 \\
\hline South Sulawesi & G. incisa & $100.05 \pm 13.02$ & 14 & 7.0 \\
\hline South Sulawesi & T. biroi & $467.93 \pm 20.58$ & 8 & 4.0 \\
\hline West Nusa Tenggara & T. fuscobalteata & $477.88 \pm 7.62$ & 7 & 3.5 \\
\hline North Maluku & T. fuscobalteata & $218.65 \pm 3.00$ & 11 & 5.5 \\
\hline
\end{tabular}

amean $\pm \mathrm{SD}, n=3$.

Numerous studies have indicated that antioxidant mechanisms in suppressing radical oxygen species (ROS) are strongly suspected to be a hepatoprotective mechanism of liver toxicity $[8,33,34]$. Propolis extract also has a hepatoprotective effect against oxidative stress [35, 36]. Furthermore, murine $\beta$ TC- 6 cell lines incubated with toxicants have increased thiobarbituric acid reactive substances (TBARs), decreased glutathione (GSH) concentrations and cell viability, and increased cell apoptosis. On the other hand, the lowered TBARs increased GSH concentrations, increased cell viability and reduced cell apoptosis were found in cells incubated with propolis extract.

Various research results have shown that propolis is able to protect the liver from mercury exposure [37] and aluminium toxicity exposure [38] through an antioxidant mechanism. It also protects the liver from the toxic effects of atorvastatin [38], ethylene glycol [39], and cypermethrin [40]. Propolis extract (150 mg/kg) has been proven to have the good hepatoprotective ability in isoniazidinduced hepatotoxicity in male albino mice [41].

However, the previous study confirmed that the results of plasma antioxidant measurements as a parameter of in vivo oxidative damage in mini pig were not aligned with the results found in rats [42]. Therefore, it was highly probable that in vitro, in vivo and clinical measurements of antioxidants were not always aligned. However, various results of the above studies can be the basis for us to establish that antioxidant capacity is an important criterion and is associated with its potential as a hepatoprotector.
Based on antioxidant capacity, G. Incisa propolis from South Sulawesi Province has the strongest potential to protect the liver from toxic effects of ATD.

\section{Toxicity}

One of ATD and anti-TB regimen requirements was safe for patients [43]. Similarly, propolis should be safe as a complementary of ATD. The safety was indicated by its toxicity. Toxicity potential was indicated by $\mathrm{LC}_{50}$ value. The higher the $\mathrm{LC}_{50}$ value, the safer the propolis. Conversely, the lower the $\mathrm{LC}_{50}$ value, the stronger the propolis toxicity.

In this examination, the test sample was liquid propolis with propylene glycol as a liquid filler. Therefore, propylene glycol was analyzed as a control. According to table 3, propylene glycol as the liquid filler had toxicity with an $\mathrm{LC}_{50}$ value of $652.49 \mathrm{ppm}$. Thus, the toxicity exhibited by propolis sample was partly derived from propylene glycol contribution. According to the propolis toxicity, there was an interesting fact that the toxicity was widespread $(<50.00$ to $>1000.00 \mathrm{ppm})$. It means that some propolis have stronger toxicity than the control (652.49 ppm), while some of them have lower toxicity.

These data suggested that there was an interaction possibility between propolis component and propylene glycol, thereby affecting its toxicity level. This phenomenon was very interesting to be learned further, in order to identify which propolis components that were synergetic, neutral or antagonist with propylene glycol. 
Table 3: Toxicity of stingless bee propolis samples from different provinces

\begin{tabular}{|c|c|c|c|c|}
\hline Province origin & Bee species & Toxicity LC ${ }_{50}(\mathrm{ppm})^{\mathrm{a}}$ & Score order & Weighting score (25\%) \\
\hline North Sumatera & T. minangkabau & $621.49 \pm 45.40$ & 7 & 1.75 \\
\hline North Sumatera & S. moorei & $55.09 \pm 12.20$ & 2 & 0.50 \\
\hline Banten & T. laeviceps & $<50.00 \pm 13.55$ & 1 & 0.25 \\
\hline West Java & T. laeviceps & $521.74 \pm 18.22$ & 5 & 1.25 \\
\hline Central Java & T. laeviceps & $615.84 \pm 21.33$ & 6 & 1.50 \\
\hline West Kalimantan & H. itama & $802.26 \pm 32.55$ & 10 & 2.50 \\
\hline East Kalimantan & H. itama & $451.32 \pm 25.35$ & 4 & 1.00 \\
\hline South Kalimantan & H. itama & $270.60 \pm 19.27$ & 3 & 0.75 \\
\hline South Kalimantan & T. laeviceps & $838.05 \pm 16.22$ & 11 & 2.75 \\
\hline South Kalimantan & G. thorasica & $>1000.00 \pm 21.76$ & 14 & 3.50 \\
\hline South Sulawesi & G. incisa & $854.75 \pm 23.82$ & 12 & 3.00 \\
\hline South Sulawesi & L. terminata & $656.41 \pm 21.10$ & 9 & 2.25 \\
\hline West Nusa Tenggara & T. fuscobalteata & $624.34 \pm 12.98$ & 8 & 2.00 \\
\hline North Maluku & T. fuscobalteata & $932.63 \pm 10.88$ & 13 & 3.25 \\
\hline
\end{tabular}

amean $\pm \mathrm{SD}, n=3$.

According to table 3, the safest propolis is propolis G. thorasica from South Kalimantan Province, with an $\mathrm{LC}_{50}$ of more than 1000.00 (score order is 14, weighting score is 3.5 ). In terms of safety, it is the best propolis. Conversely, the most toxic propolis is T. laeviceps propolis from Banten Province, with an $\mathrm{LC}_{50}$ of less than 50.00 (score order is 1 , weighting score is 0.25 ).

As is the case with antioxidant capacity, the difference in the toxicity of propolis is influenced by bee species and plant species of resin sources. A study result suggested that the difference in the toxicity of propolis might be due to the differences in the composition of the active compounds it contained and each active compound had different toxicity levels [44]. The results of this toxicity test were also in line with another study which suggested that the biological activity and phytochemical composition were influenced by the geographical location and the plant origin of the resin [31].

G. thorasica bee propolis (the lowest toxicity) is derived from the resin of jackfruit (Artocarpus heterophyllus), mangosteen (Garcinia mangostana), durian (Durio zibethinus), mango (Mangifera indica), and lead tree (Leucaena leucocephala). These data regarding resin source plant provide clues that the low toxicity of $G$. thorasica propolis is influenced by plant food resins that are usually non-toxic.

The highest toxicity occurs in the liver, followed by brain and kidneys [45]. Therefore, propolis toxicity becomes one of the considerations in the determination of ATD complementary nutraceutical candidate. Numerous studies have shown that propolis has low liver toxicity. Behavior changes and clinical toxicity were not found in experimental mice receiving an ethanolic extract of propolis up to a dose of $2000 \mathrm{mg} / \mathrm{kg}$ body weight (BW) during a 45-d study.
Nevertheless, there were hematological and biochemical changes at that dose compared to the control [46]. Another study on Swiss mice also showed no signs of toxicity in the propolis hydroalcoholic extract administration with doses of 1000, 2000 and $4000 \mathrm{mg} / \mathrm{kg}$ BW. No death was found in all the treatment groups, and blood biochemical analysis showed decreased levels of alanine aminotransferase (ALT) and alkaline phosphatase (ALP) indicating that propolis was hepatoprotective [44]. Toxic effects were undetectable in mice receiving $25 \mu \mathrm{l}$ propolis/administration four times a day [47]. Furthermore, adult female Sprague-Dawley mice receiving $200 \mathrm{mg}$ propolis/d orally were able to resist the toxic effects of oral administration of $200 \mathrm{mg}$ methoxychlor/kg BW twice a week [48]. A review stated that $\mathrm{LD}_{50}$ of propolis in various mouse species ranged from 300 to $2050 \mathrm{mg} / \mathrm{kg}$ [49].

However, we recognize that BSLT method cannot be a strong basis for the determination of toxicity, but these data are useful for early predictions of propolis toxicity. Further toxicity analysis should be performed on the determined candidates to establish the propolis that is eligible to be declared a complementary nutraceutical of ATD.

\section{Mycobacterium tuberculosis strain $\mathrm{H37Rv}$ inhibitory activity}

Various studies have revealed that propolis has the ability against $M t b$ germ and synergizes with ATD $[19,22]$. Therefore, propolis ability in inhibiting $M t b H 37 R v$ becomes one of the considerations in our study.

In the present study, rifampicin with a concentration of $0.02 \%$ (positive control) consistently showed no colony growth of $M t b H 37 R v$ or $100 \%$ inhibition. In contrast, $100 \%$ colony growth or $0 \%$ inhibition were found in negative control (without rifampicin or propolis).

Table 4: Mycobacterium tuberculosis strain H37Rv inhibition activity of stingless bee propolis samples from different provinces

\begin{tabular}{|c|c|c|c|c|c|c|}
\hline Province origin & Bee species & MPN a & $\begin{array}{l}\text { Growth of } m t b \\
(\%)\end{array}$ & $\begin{array}{l}\text { Mtb inhibition } \\
\text { activity (\%) }\end{array}$ & Score order & $\begin{array}{l}\text { Weighting } \\
\text { score }(25 \%)\end{array}$ \\
\hline $\begin{array}{l}\text { Positive control } \\
\text { (rifampicin) }\end{array}$ & - & $0.0 \pm 0.0$ & 0.00 & 100.00 & - & - \\
\hline Negative control & - & $157.5 \pm 7.5$ & 100.00 & 0.00 & - & - \\
\hline North Sumatera & T. minangkabau*) & - & - & - & - & - \\
\hline North Sumatera & S. moorei & $106.5 \pm 1.5$ & 67.62 & 32.38 & 6 & 1.50 \\
\hline Banten & T. laeviceps & $155.0 \pm 0.0$ & 98.41 & 1.59 & 1 & 0.25 \\
\hline West Java & T. laeviceps & $150.0 \pm 0.0$ & 95.24 & 4.76 & 3 & 0.75 \\
\hline Central Java & T. laeviceps & $137.5 \pm 2.5$ & 87.30 & 12.70 & 4 & 1.00 \\
\hline West Kalimantan & H. itama & $152.5 \pm 2.5$ & 96.83 & 3.17 & 2 & 0.50 \\
\hline East Kalimantan & H. itama & $120.0 \pm 0.0$ & 76.19 & 23.81 & 5 & 1.25 \\
\hline South Kalimantan & H. itama & $150.0 \pm 0.0$ & 95.24 & 4.76 & 3 & 0.75 \\
\hline South Kalimantan & T. laeviceps*) & - & - & - & - & - \\
\hline South Kalimantan & G. thorasica & $35.0 \pm 5.0$ & 22.22 & 77.78 & 8 & 2.00 \\
\hline South Sulawesi & G. incisa & $79.0 \pm 11.0$ & 50.16 & 49.84 & 7 & 1.75 \\
\hline South Sulawesi & T. biroi & $0.0 \pm 0.0$ & 0.00 & 100.00 & 9 & 2.25 \\
\hline West Nusa Tenggara & T. fuscobalteata & $0.0 \pm 0.0$ & 0.00 & 100.00 & 9 & 2.25 \\
\hline North Maluku & T. fuscobalteata & $152.5 \pm 2.5$ & 96.83 & 3.17 & 2 & 0.50 \\
\hline
\end{tabular}

amean $\pm \mathrm{SD}, n=3,{ }^{*}$ ) the data were eliminated due to the failed test. 
It was interesting that different propolis had different $M t b H 37 R v$ inhibitory capability. At the same level as rifampicin, T. laeviceps propolis from Banten Province showed a very low inhibition of $1.59 \%$ (score order was 1, weighting score was 0.25 ). Meanwhile, $T$. biroi propolis from South Sulawesi Province and T. fuscobalteata propolis from West Nusa Tenggara Province showed maximum inhibition (100\%) with score order of 9 and weighting score of 2.25 . Their abilities were equivalent to rifampicin.

The investigation results regarding plant origin of the resin showed that T. fuscobalteata propolis from West Nusa Tenggara Province collected resin from Ceara rubber tree (Manihot glaziovii), mangosteen (Garcinia mangostana), mango (Mangifera indica), jackfruit (Artocarpus heterophyllus), cempedak (Artocarpus integer), durian (Durio ziberthinus), pomelo (Citrus maxima), banana (Musa spp.), and castor oil plant (Ricinus communis). The resin source plants were divided into two groups; i.e. medicinal plants and food plants. The medicinal plants were Ceara rubber tree (Manihot glaziovii), mangosteen (Garcinia mangostana), pomelo (Citrus maxima), and castor oil plant (Ricinus communis). Meanwhile, the food plants were mangosteen (Garcinia mangostana), mango (Mangifera indica), jackfruit (Artocarpus heterophyllus), cempedak (Artocarpus integer), durian (Durio ziberthinus), pomelo (Citrus maxima), and sweet orange (Citrus sinensis). The resin source plants of T. fuscobalteata from West Nusa Tenggara Province had similarities with the resin source plants of $G$. incisa propolis and T. biroi propolis from South Sulawesi that were dominated by medicinal plants, which had an effect on the strong $M t b$ inhibition activity. In this study, it appeared that the more the resins from medicinal plants, the stronger the biological activity and toxicity of the propolis. Conversely, the more the resins from food plants, the weaker the biological activity and toxicity.

This study strengthens the results of various previous studies which have shown that the antimycobacterial activity of propolis varies. The water extract of propolis has a low $M t b H 37 R v$ inhibitory ability [50]. In contrast, numerous studies have indicated that ethanol extract of propolis has good Mtb inhibitory ability [19-22, 31, 51, 52].

The difference in the inhibitory of $M t b H 37 R v$ strengthens the opinion that biological activity of propolis is diverse and influenced by the content of its active compounds [31]. In our study, the differences were allegedly influenced by different species of bees and the origin of plant resins.
Our study showed that T. biroi propolis from South Sulawesi and T. fuscobalteata propolis from West Nusa Tenggara Province were the best propolis in inhibiting $M t b H 37 R v$. However, this test had limitations. There were two $M t b H 37 R v$ inhibitory data not available due to test failure and lack of test samples; i.e. T. minangkabau propolis from North Sumatera Province and T. laeviceps propolis from South Kalimantan Province. Both of them might have a stronger ability to inhibit $M t b H 37 R v$ than other propolis.

\section{Determination of the best candidate}

The best candidate was determined by three determinant parameters; i.e. antioxidant capacity, toxicity, and inhibition of $M t b$. Antioxidant capacity was the main criterion because the primary mechanism to protect the liver from the toxic effects of ATD was to reduce the oxidant radical of ATD metabolites.

Moreover, additional criteria were safety (low toxicity) and having good ability to inhibit $M t b H 37 R v$. Therefore, antioxidant capacity, toxicity, and $M t b H 37 R v$ inhibition were given the weight of $50 \%$, $25 \%$, and $25 \%$, respectively. The selected propolis candidate was the one with the highest total score. With these three criteria, the ATDcomplementary propolis was expected to have a major ability as hepatoprotector, as a solution of one of the main problems in the use of ATD. In addition, ATD-complementary propolis was also safe (not toxic) and having good ability to fight $M t b$ infection.

The highest score was achieved by G. incisa propolis originating from South Sulawesi Province, with a score of 11.75. The score was mainly obtained from antioxidant activity (7.0), toxicity (3.0) and Mtb H37Rv inhibition (1.75). An antioxidant capacity score of this propolis was the highest compared to other propolis samples. Meanwhile, in terms of toxicity, this propolis was not the safest. There were two safer propolis samples; i.e. G. thorasica propolis from South Kalimantan Province with a score of 3.50 and $T$. fuscobalteata propolis from North Maluku Province with a score of 3.25. Likewise in the Mtb $H 37 R v$ inhibition, this propolis was not the strongest. There were three samples of propolis which had stronger $M t b$ inhibition; i.e. T. biroi propolis from South Sulawesi Province and T. fuscobalteata propolis from West Nusa Tenggara Province that had the same score (2.25), as well as G. thorasica propolis from South Kalimantan Province with a score of 2.00 .

Tabel 5: Determination of the best candidate

\begin{tabular}{|c|c|c|c|c|c|}
\hline \multirow[t]{2}{*}{ Province origin } & \multirow[t]{2}{*}{ Bee species } & \multirow{2}{*}{$\begin{array}{l}\text { Antioxidant activity } \\
\text { W. score }(50 \%)\end{array}$} & \multirow{2}{*}{$\begin{array}{l}\text { Toxicity } \\
\text { W. score }(25 \%)\end{array}$} & \multirow{2}{*}{$\begin{array}{l}\text { Mtb inhibition activity } \\
\text { W. score }(25 \%)\end{array}$} & \multirow[t]{2}{*}{ Total score } \\
\hline & & & & & \\
\hline North Sumatera & T. minangkabau & 0.5 & 1.75 & - & 2.25 \\
\hline North Sumatera & S. moorei & 6.0 & 0.50 & 1.50 & 8.00 \\
\hline Banten & T. laeviceps & 6.5 & 0.25 & 0.25 & 7.00 \\
\hline West Java & T. laeviceps & 3.0 & 1.25 & 0.75 & 5.00 \\
\hline Central Java & T. laeviceps & 4.5 & 1.50 & 1.00 & 7.00 \\
\hline West Kalimantan & H. itama & 5.0 & 2.50 & 0.50 & 8.00 \\
\hline East Kalimantan & H. itama & 1.0 & 1.00 & 1.25 & 3.25 \\
\hline South Kalimantan & H. itama & 2.0 & 0.75 & 0.75 & 3.50 \\
\hline South Kalimantan & T. laeviceps & 2.5 & 2.75 & - & 5.25 \\
\hline South Kalimantan & G. thorasica & 1.5 & 3.50 & 2.00 & 7.00 \\
\hline South Sulawesi & G. incisa & 7.0 & 3.00 & 1.75 & 11.75 \\
\hline South Sulawesi & T. biroi & 4.0 & 2.25 & 2.25 & 8.50 \\
\hline West Nusa Tenggara & T. fuscobalteata & 3.5 & 2.00 & 2.25 & 7.75 \\
\hline North Maluku & T. fuscobalteata & 5.5 & 3.25 & 0.50 & 9.25 \\
\hline
\end{tabular}

Based on these three test parameters, G. incisa propolis from South Sulawesi Province was chosen as the best candidate of complementary nutraceutical of ATD. It had the following characteristics: 1) had the strongest potential to reduce the hepatotoxic effects of ATD, 2) had low toxicity potential, and 3) had strong potential to inhibit Mtb infection.

\section{CONCLUSION}

Based on the antioxidant capacity test, the highest score was owned by $G$. incisa propolis from South Sulawesi Province. The toxicity test indicated that $G$. thorasica propolis from South Kalimantan Province had the lowest toxicity. Furthermore, Mtb H37Rv inhibition test showed that the highest score was achieved by T. biroi propolis from
South Sulawesi Province and T. fuscobalteata propolis from West Nusa Tenggara Province. Based on all test parameters, the highest score was achieved by $G$. incisa propolis from South Sulawesi Province. Thus, it was defined as ATD complementary nutraceutical candidate. Further studies on animal models and clinical studies are needed to establish this propolis as the complementary nutraceutical of ATD. 


\section{ACKNOWLEDGEMENT}

We would like to thank the Directorate General of Higher EducationIndonesian Ministry of Research, Technology and Higher Education for the Research Grant 2015-2017. Mahani as the principal investigator designed the research, directed the research, and wrote the paper. Sulaeman and Hardinsyah received International Research Collaboration and Scientific Publication Research grant for Mycobacterium tuberculosis inhibition testing of propolis. They interpreted the data and wrote the paper. Anwar and Damanik designed the research (antioxidant and toxicity testing), interpreted the data, and wrote the paper. Ploeger as an international partner and wrote the paper.

\section{AUTHORS CONTRIBUTIONS}

All the author have contributed equally

\section{CONFLICT OF INTERESTS}

The authors declare no conflict of interest

\section{REFERENCES}

1. [WHO] World Health Organization. Global tuberculosis report 2016. Geneva: WHO Press; 2016.

2. Chowdhury A, Santra A, Bhattacharjee K, Ghatak S, Saha DR, Dhali GK. Mitochondrial oxidative stress and permeability transition in isoniazid and rifampicin-induced liver injury in mice. J Hepatol 2006;45:117-26.

3. [WHO] World Health Organization. Global tuberculosis report 2013. Geneva: WHO Press; 2013.

4. Sudarsanam TD, Tharyan P. Rifampicin compared to isoniazid for preventing active TB in HIV-negative people at risk of developing active tb: implications for public health. Clin Epidemiol Global Health 2014;2:28-36.

5. Sari ID, Yuniar Y, Syaripuddin M. The monitoring study of category 1 FDC anti-tuberculosis drug side effects in Banten Province and West Java Province. Media Litbangkes: Indonesian J Health Res Dev 2014;24:28-35.

6. Lombardo CC, Swart R, Visser ME. The nutritional status of patients with tuberculosis in comparison with tuberculosisfree contacts in Delft, Western Cape. S Afr J Clin Nutr 2012;25:180-5.

7. Yew WW, Leung CC. Antituberculosis drugs and hepatotoxicity. Respirol 2006;11:699-707.

8. Jimenez-Arellanes MA, Gutierrez-Rebolledo GA, Meckes-Fischer M, Leon-Diaz R. Medical plant extracts and natural compounds with a hepatoprotective effect against damage caused by antitubercular drugs: a review. Asian Pac J Trop Med 2016;9:1141-9.

9. Bhadauria M, Nirala SK, Shukla S. Duration-dependent hepatoprotective effects of propolis extract against carbon tetrachloride-induced acute liver damage in rats. Adv Ther 2007;24:1136-45.

10. Hashmi N, Muhammad F, Javed I, Khan JA, Khan MZ, Khaliq T, et al. Nephroprotective effects of Ficus religiosa linn (peepal plant) stem bark against isoniazid and rifampicin-induced nephrotoxicity in albino rabbits. Pak Vet J 2013;33:330-4.

11. Cevik MU, Acar A, Tanriverdi H, Varol S, Arikanoglu A, Yucel Y, et al. Toxic effects of isoniazid and rifampicin on rat brain tissue: the preventive role of caffeic acid phenethyl ester. Int J Pharmacol 2012;8:555-60.

12. Ramadan A, Soliman G, Mahmoud SS, Nofal SM, Abdel-Rahman SF. Hepatoprotective and hepatotherapeutic effects of propolis against d-galactosamine/lipopolysaccharide-induced liver damage in rats. Int J Pharm Pharm Sci 2015;7:372-8.

13. Omar NAA, Allithy ANEA, Baghdadi H, Zolaly M, Abdel-haleem M, Helmy MM, et al. Hepatoprotective effects exerted by propolis against doxorubicin-induced rat liver toxicity: a biochemical and histopathological study. Am J Cancer Prev 2016;4:36-40.

14. Bharti U, Kumar NR, Kaur J. Protective effect of bee propolis against anti-tuberculosis drugs (rifampicin and isoniazid)induced hematological toxicity in sprague dawley rats. Asian J Pharm Clin Res 2017;10:188-90.

15. Kothai S, Jayanthi B. Evaluation of antioxidant and antimicrobial activity of stingless bee propolis (Tetragonula iridipennis) of Tamilnadu, India. Int J Pharm Pharm Sci 2014;6:81-5.

16. Pujirahayu N, Ritonga H, Agustina S, Uslinawaty Z. Antibacterial activity of oil extract of trigona propolis. Int J Pharm Pharm Sci 2015;7:419-22.

17. Rozanna R, Soedarsono N, Farida R. Effect of propolis extract and propolis candies on the growth of Streptococcus sanguinis ATCC 10556. Asian J Pharm Clin Res 2017;10:16-9.

18. Erlianda D, Rizal MF, Budiardjo SB. Antibacterial effect of flavonoids from propolis produced by trigona on ATPase activity of Streptococcus mutans. Int J Appl Pharm 2017;9:6-9.

19. Wahyunitisari MR, Mertaniasih NM, Rachmawati D. Antimicrobial activities of andrographolide and propolis against intracellular Mycobacterium tuberculosis phagocytosed by monocytes derived macrophages. Folia Medica Indonesiana 2006;42:22-7.

20. Scazzocchio F, D'Auria FD, Alessandrini D, Pantanella F. Multifactorial aspects of antimicrobial of propolis. Microbiol Res 2006;161:327-33.

21. Scheller S, Dworniczak S, Waldemar-Klimmek K, Rajca M, Tomczyk A, Shani J. Synergism between ethanolic extract of propolis (EEP) and anti-tuberculosis drugs on growth of mycobacteria. Z Naturforsch 1999;54:549-53.

22. Krol W, Scheller S, Shani J, Pietsz G, Czuba Z. Synergistic effect of ethanolic extract of propolis and antibiotics on the growth of Staphylococcus aureus. Arzneimittelforschung 1993;43:607-9.

23. Cottica SM, Sawaya ACHF, Eberlin MN, Franco SL, Zeoulae LM, Visentainera JV. Antioxidant activity and composition of propolis obtained by different methods of extraction. J Braz Chem Soc 2011;22:929-35.

24. Mirzaei A, N Mirzaei N, Ghavamizadeh M. Antioxidant activity and cytotoxicity of Dorema aucheri by Artemia urmiana: a brine shrimp lethality test. Life Sci J 2013;10:8-12.

25. Dong $\mathrm{Y}$, Huang J, Lin X, Zhang S, Jiao J, Liang $\mathrm{T}$, et al. Hepatoprotective effects of yulangsan polysaccharide against isoniazid and rifampicin-induced liver injury in mice. J Ethnopharmacol 2014;152:201-6.

26. Rasmussen C, Cameron SA. Global stingless bee phylogeny supports ancient divergence, vicariance, and long-distance dispersal. Biol J Linnean Soc 2010;99:206-32.

27. Eminzade $S$, Uras F, Izzettin FV. Silymarin protects liver against toxic effects of anti-tuberculosis drugs in experimental animals. Nutr Metab 2008;5:1-8.

28. Asadi-Samani M, Kafash-Farkhad N, Azimi N, Fasihi A, AliniaAhandani E, Rafieian-Kopaei M. Medicinal plants with hepatoprotective activity in iranian folk medicine. Asian Pac J Trop Biomed 2015;5:146-57.

29. Huang WJ, Huang C, Wu C, Lin J, Chen Y, Lin C, et al. Propolin G, a prenylflavanone, isolated from taiwanese propolis, induces caspase-dependent apoptosis in brain cancer cells. J Agric Food Chem 2007;55:7366-76.

30. Hu YQ, Zhang S, Zhao F, Gao C, Feng LS, Sheng Z, et al. Isoniazid derivatives and their anti-tubercular activity. European J Med Chem 2017;133:255-67.

31. Bankova V. Recent trends and important developments in propolis research. eCAM 2005;2:29-32.

32. Naik SR, Panda VS. Hepatoprotective effect of Ginkgoselect Phytosome $\AA$ in rifampicin induced liver injury in rats: evidence of antioxidant activity. Fitoterapia 2008;79:439-45.

33. Ghaffari H, Venkataramana M, Nayaka SC, Ghassam BJ, Angaswamy N, Shekar S, et al. Hepatoprotective action of Orthosiphon diffusus (benth.) methanol active fraction through antioxidant mechanisms: an in vivo and in vitro evaluation. J Ethnopharmacol 2013;149:737-44.

34. Han J, Li D, Chen X, Meng F, Wang B, Zhang X, et al. Hepatoprotective activities of huoshan dendrobium officinale kimura et migo water extracts on carbontetrachloride-induced hepatotoxicity in mice. J Food Nutr Res 2016;4:543-8.

35. Zagmutt S, Leiva E, Mujica V, Wehinger S. Protective effect of propolis extract on pancreatic $\beta$ cell under oxidative stress in vitro. J Food Nutr Res 2016;4:400-7.

36. Boutabet K, Kebsa W, Alyane M, Lahouel M. Polyphenolic fraction of Algerian propolis protects rat kidney against acute oxidative stress induced by doxorubicin. Indian J Nephrol 2011;21:101-6. 
37. Nirala SK, Bhadauria M. Propolis reverses acetaminophen induced acute hepatorenal alterations: a biochemical and histopathological approach. Arch Pharm Res 2008;31:451-61.

38. Türkez H, Yousef MI, Geyikoglu F. Propolis protects against 2,3,7,8-tetrachlorodibenzo-p-dioxin-induced toxicity in rat hepatocytes. Food Chem Toxicol 2012;50:2142-8.

39. El Menyiy N, Al Waili N, Bakour M, Al-Waili H, Lyoussi B. Protective effect of propolis in proteinuria, crystaluria, nephrotoxicity and hepatotoxicity induced by ethylene glycol ingestion. Arch Med Res 2016;47:526-34.

40. Abdul-Hamid M, Moustafa N, Asran AMA, Mowafy L. Cypermethrin-induced histopathological, ultrastructural and biochemical changes in liver of albino rats: the protective role of propolis and curcumin. Beni-Suef Univ J Basic Appl Sci 2017;6:160-73.

41. Humayun F, Tahir M, Lone KP, Munir B, Ahmad A, Latif W. Protective effect of ethanolic extract of propolis on isoniazid induced hepatotoxicity in male albino mice. Biomedica 2014;30:85-91.

42. Kadiiska MB, Peddada S, Herbert RA, Basu S, Hensley K, Jones $\mathrm{DP}$, et al. Biomarkers of oxidatives tress study VI. Endogenous plasma antioxidants fail as useful biomarkers of endotoxininduced oxidative stress. Free Radical Biol Med 2017;81:100-6.

43. Zhenkun M, Lienhardt C, McIlleron H, Nunn AJ, Wang X. Global tuberculosis drug development pipeline: the need and the reality. Lancet 2010;375:2100-9.

44. Araujo MJAM, Mattar NS, Reis AS, Serra ICPB, Fialho EMS, Assunção AKM, et al. Pharmacognostic and acute toxicological evaluation of scaptotrigona aff. postica propolis extract in preclinical assays. Nat Prod Res 2011;25:1037-46.
45. Kumar V, Kalita J, Bora HK, Misra UK. Relationship of antioxidant and oxidative stress markers in different organs following copper toxicity in a rat model. Toxicol Appl Pharmacol 2016;293:37-43.

46. Mohammadzadeh S, Shariatpanahia M, Hamedi M, Ahmad KR, Samadi N, Ostad SN. Chemical composition, oral toxicity and antimicrobial activity of Iranian propolis. Food Chem 2007;103:1097-103.

47. Liberio SA, Pereira ALA, Dutra RP, Reis AS, Araújo MJAM, Mattar NS, et al. Antimicrobial activity against oral pathogens and immunomodulatory effects and toxicity of geopropolis produced by the stingless bee Melipona fasciculata smith. BMC Complementary Altern Med 2011;11:1-10.

48. El-Sharkawy EE, Kames AOG, Sayed SM, Nisr NAEL, Wahba NM, Elsherif WM, et al. The ameliorative effect of propolis against methoxychlor induced ovarian toxicity in rat. Exp Toxicol Pathol 2014;66:415-21.

49. Burdock GA. Review of the biological properties and toxicity of bee propolis (propolis). Food Chem Toxicol: Int J Publ Br Ind Biol Res Assoc 1998;36:347-50.

50. Yildirim Z, Hacievliyagil S, Kutlu NO, Aydin NE, Kurkcuoglu M, Iraz $\mathrm{M}$, et al. Effect of water extract of Turkish propolis on tuberculosis infection in guinea-pigs. Pharm Res 2004;49:287-92.

51. Scheller S, Kawalski H, Oklek K, Dworniczak S, Matsuno T, Klimmek W, et al. Correlation between virulence of various strains of mycobacteria and their susceptibility to ethanolic extract of propolis. Z Naturforsch 1998;53:1040-4.

52. Syamsudin, Rosilawati ML, Cita YP. Antimycobacterial and antiplasmodial activities of extract of propolis from different region in Java (Indonesia). Aust J Basic Appl Sci 2011;5:1030-4. 